\title{
Western Crisis, Asian Identities, and Cultural Power
}

\author{
RAYMOND L.M. LEE
}

\begin{abstract}
The crisis of modernity in the West has problematized the notion of culture. Sweeping changes in mass communications, emergence of new social movements, intensification of cultural experiences, and strident voices of minority groups have contributed to altered perceptions of self and collective identities. Furthermore, the failure of the West to maintain structural dominance in the economic sphere has opened the way for increased debates about the power of culture. These emerging issues in the West may have a significant impact on Asian societies that are experiencing economic growth, since they are struggling to acquire a modern identity without losing their traditional referents. A growing recognition of multiculturalism and cultural resources in the West may in the long run influence the formation of an Asian modernity in which cultural assertiveness dictates the terms of socio-economic development. The aims of this article are to delineate some reasons for the rediscovery of culture, its ideological and practical consequences, and their implications for the future of Asian and Western development.
\end{abstract}

\section{Introduction}

The end of the 20th century has been marked by a massive shift to cultural issues. Culture now occupies a special position as an independent variable, where once it had been considered epiphenomenal to economics and politics. In a recent textbook on culture, Hall and Nietz (1993: 1) claimed that for many representatives of the social sciences and humanities, 'culture has come to be something of a missing link'. This comment suggests a paradigmatic shift which reflects important changes in the Western perception of modernity.

First, the crisis of capitalism in the West (Lash and Urry 1987) has led not only to the decline of mass industrial production but also to the exportation of capitalism to the less industrialized countries, thus 
opening up more competitive markets in the Asian sphere. In terms of globalization, the uncertainties of late capitalism have gradually reduced the economic confidence of the West and with it the predictability of continued worldwide domination of markets. For the first time in the history of Western modernity, Asian alternatives have arisen to challenge the previously undisputed economic hegemony of the West. This implies that globalization of markets cannot necessarily guarantee a return to the position of economic dominance once assumed by the West.

Second, the growing spectre of cultural fragmentation in the West has made irrelevant the distinction between high and popular culture. This has opened the way for an intensification of cultural production, a process in which 'cultural components proliferate, split off and recombine in ways which do not correspond to any supposed "logic" of modernity' (Crook et al. 1992: 229). In other words, culture and its various trajectories of consumption are no longer seen as servants of material interests but as more or less autonomous influences over different spheres of society. What is globalized then are cultural lifestyles which can connect in different permutations with local perceptions and practices.

The decline of Western economic hegemony has empowered the reformation of culture as a dynamic global force that appears to be 'self-sufficient' and 'free to move anywhere in socio-cultural space and to enter promiscuously into relations with almost any other fragment' (Crook et al. 1992: 75). Thus, the shift from economics to culture may be seen as an attempt to wrest the power of representation in culture from the waning framework of economic absolutism, and in the process come to redefine world development not directly as a function of capitalist designs but as emerging patterns of simulacra, kitsch, hypercommodification, and aesthetic populism that level as well as invigorate personal experiences around the world.

Through culture, modernity receives a new lease of life without direct reference to changes in economic structure while enhancing an image of irreversible globality, even though this globality may only reflect a Western problem of identity reformation. For this reason, cultural agency in the present context has become an almost indispensable codeword for the renewal of the Western self in relation to changing Asian identities. 
This article aims to outline the ideological and practical dimensions of cultural empowerment in the West and Asia, and to assess the impact of these changes on the concept of development. These problems will also be discussed in terms of the metaphysics of cultural power, that is, the difference between Western and Asian perceptions of being (or the meaning of existence) and its significance for social and cultural change.

\section{From Class to Culture}

The achievements of post-feudal Western society propelled the Western self into a quest for world-systemization and globalization. They instilled in the very fibre of Western culture the 'oughtness' of the self, that all thoughts and actions have a more or less perfect correlation with the empirical world. Yet, it is this very process of self-creation that has now imploded on itself through the reflexive component of identity-formation.

For at least the last two centuries, the core of the Western self has been defined mostly by class politics. Western self-identity was in many respects the engineering of class identity, and Marx contributed enormously to the making of this identity in the hope of attaining self-emancipation. In his view, the worker in capitalist industrial societies was alienated from the products of his labour, and in that respect his labour was dead, and the self of the worker became marginalized. The role of the revolutionary proletariat was to breathe life into labour and to lift the veil of false consciousness from the workers in order to usher in a socialist identity for the disentanglement of the estranged self. But this is only possible if reflexivity is an independent force unblemished by the externalities of capitalist relations of production. This optimism of Marxist emancipation continues to invigorate the socialist vision of theorists who see the battle of class identity as just beginning with the decline of Western capitalism (e.g. Petras and Vieux 1994).

But this optimism for the revival of class identity in the West is not equally shared by all critical theorists. Aronowitz (1992: 8), for instance, believes that over the last two decades class identity no longer commands attention in contemporary American politics. Instead, it has been displaced in other identities for which the context of their appearance counts most and not their structural 
positions. He suggests that the electronic media in the United States have played such a large role in the formation of cultural identities that their displacement of working-class representations have effectively erased the 'class sensorium' (ibid.: 199-200). In other words, the defining characteristic of Western identity has become less dominated by class politics, which now shares the same social space as the social movements emerging from gender, minority and environmental concerns.

These new social movements have no structural precedents and would seem to embody a new reflexivity unlike other identity struggles experienced in the past (cf. Melucci 1989). The new reflexivity engendered by these movements has brought the margins into confrontation with the older identities based on mass production, consumerism and conformism (see Steinmetz 1994). It is an open-ended reflexivity that impugns the various aspects of organized capitalism but in itself cannot fully determine the outcome of this confrontation.

In the midst of the uncertainty, fragmentation and marginality accompanying the new social movements in the West, it is not difficult to envisage the revival of traditional lifeworlds through the intensification of cultural sentiments as a stabilizing alternative to the identity unrest experienced in a period of transition. Two effects of this alternative are apparent.

First, the revival of nationalism in many parts of Europe is likely to pre-empt any possible resurfacing of class identity. This revival delivers a coup de grâce to the fading traces of the socialist experiment in 20th-century Europe. Thus, to preserve political economy without being rigidly determinist calls for a post-class identity that stretches from a post-Marxist radical democracy (Mouffe 1988) to the aleatory conditions of regulation theory (Steinmetz 1994). For the reflexivity implied in class identity can no longer be taken for granted or assumed to be an iron-clad condition of revolutionary change, since the revision of Marxism to an ideology without guarantees (Hebdige 1988: 207) must necessarily arrive at a compromise with the recognition of the power inherent in culture.

Second, these identity claims have created more marginal positions. Each claim pertains to a reclamation of a pristine cultural past to authenticate and empower a lost or subordinated identity. And many such claims seek articulation in the face of declining class 
politics, thus increasing the field of minority voices and the pace for demarcating horizontal boundaries without the restraints once provided by class organization.

On the one hand, the crisis of identity in the West poses a question concerning the destiny of the West as modernity unravels beyond postmodernity into something else. This destiny is being fought out among neo-Marxists, post-Marxists, neo-liberals, post-liberals, neonationalists, and so forth. On the other hand, 'this crisis has impacted on Asians in a way not expected by them. As Western identity becomes unfixed in postmodernity, Western observers are attempting to refix Asian identities' (Lee 1994a, 1997).

During the colonial period, Asian identities were subordinated to the authorization of the Western world. If there was resistance or attempt to speak, the Asian voice could only be heard through a Western authority as it prepared to crush the resistance or to adjudicate the former's claims. In the post-colonial period, the disarray of Western identity has emboldened the Asian voice to speak on behalf of many specific identities that do not necessarily correspond to those emerging in the new social movements in the West. The identities of the new movements signal a disillusionment with modernity. On the contrary, Asian identities attempt to ride on the coat-tails of modernity to demand what they think they have missed out.

This brief comparison implies that identity-formation in the Western and Asian spheres is linked, particularly through the colonial experience, but the outcomes are vastly different. As a result of that experience, Western identity is attempting to shed its universal image in order to ask what particular possibilities can be achieved without resort to an ultimate foundation. However, Asian identities emerging from the chrysalis of Western despair do not reject universalism but are trying to appropriate some of it for moulding their own particularities. It is at this crossroads, what Mouffe (1988: 36) refers to as 'a new kind of articulation between the universal and the particular', that the cruelty of identity is deeply felt - for the empirical world 'demands identity but cannot offer clear directions in the making of identities'. 


\section{The Imperialism of Culture}

The present experience of culture in the West is implosive, which means to say that culture is anything and everything (cf. Marien 1993). In anthropological parlance, culture once referred to the customs, beliefs and practices of particular peoples separated in space and time from other peoples with different cultural patterns. Culture was conceptualized as a critical signpost of identity routinized and institutionalized in daily practice, but at the same time maintaining perceptions of difference. Now culture weaves in and out of personal experiences and is thought to have no necessary referents. As it becomes globalized, it moves further and further away from our understanding of tradition and anchorage because it is now described as 'eclectic, universal, timeless and technical' (Smith 1990: 177). From the film factories of Hollywood to the mass pleasures of the tourist industry, the vibrancy of culture in its myriad manifestations has turned each and every individual into a connoisseur of art, food, history and so on.

But it is also in these cultural changes that we can see the potential for the generation of differences and conflicts. Smith (1990: 185) recognizes that:

communities in their struggle for political rights and recognition have drawn upon their cultural resources ... to make their mark in the wider political arena, regionally and internationally, and continue to do so by the use of comparative statistics, prestige projects, tourism and the like.

It is in these struggles that voices from the margins have carved out bigger stakes in the manipulation and projection of identity issues. By using new communications technologies, these groups have made themselves more visible and in that way, cultural issues have attained a high public profile (Aronowitz 1992: 26).

On the other hand, the Asian experience of culture has been largely inward-looking to maintain traditions, hierarchies and a continuing sense of community. Through written or oral traditions, the referents of Asian cultural meanings have provided some stability in lifeworld communications. However, the increased diasporas of Asian populations to the West in the latter half of the 20th century have contributed to the erosion of this communication stability, opening up opportunities for the cooptation of Asian 
Raymond Lee

cultural products for broadening the experience of Western cultural implosion.

Herein lies the subtlety of contemporary forms of cultural imperialism. Unlike economic imperialism, which is to some extent measurable in terms of capital inputs and profit outflows, cultural imperialism is not readily quantifiable. The levelling of culture through syncretization, globalization and marketing attests to an exploitable plasticity of lived experiences in food, film, literature, art and so on, that is readily reified in everyday consciousness as the openness and enrichment of life itself.

When cultural innovation is preceded by economic imperialism, the desire for cultural products tends to be influenced by established power images. To possess, imitate, or long for a cultural lifestyle in the image of those who have economic control is symbolically to request a transfer of such power. Cultural exploitation is hardly noticeable because economic exploitation is already a subjugating factor and cultural desires are merely the effects of an established hierarchy of caste and class relationships. However, the waning of economic imperialism implies that the underlying structure of power relations cannot be maintained indefinitely as a function of naked economic exploitation.

Put another way, economic imperialism is essentially a temporal movement of capital and political power. It therefore dominates and colonizes spatial relations expressed in terms of cultural exchange, imitation or negotiation. When this imperialism declines, its temporality becomes displaced by the spatiality of cultural relations. It is in this space of power that cultural imperialism can plausibly extend its influence without much obviousness. Hence, the concern over cultural matters in an era of increasing globalization directs attention to ideas, images and interpretations that have become pivotal in relations of dominance and control (cf. Robertson 1992: 183).

\section{Cultural Studies and Asian Identities}

In the West the imperialism of culture, or at least the ideological underpinnings of a dominant culture, has not gone untheorized as a lived symbol of stratification. Gender and minority studies have carved out significant areas of theorization, but it is in the expanding field of cultural studies that questions concerning the meaning and 
consequences of cultural production have become more prevalent and, perhaps, more globalized.

Cultural studies as an emerging field of critical theories and methodologies (Agger 1992; Harris 1992; Jenks 1993; Inglis 1993) represents a disparate grouping of scholars from various disciplines whose concerns with cultural production, change and power in Western societies have intensified their search for articulations between culture and society. As Grossberg (1993: 2) sees it:

Cultural studies neither applies theory as if answers could be known in advance, nor is it empiricism without theory. [It] is committed to the detour through theory even though it is not theory driven; it is driven by its own sense of history and politics.

What this suggests is that the leitmotif of cultural studies is rooted in the Western problematic of the making and remaking of society through the apparent autonomy and individuality of cultural agency. In articulating this problematic, the pioneering efforts of British cultural studies in the 1970s focused specifically on the symbolic resistance of working-class males (Hall and Jefferson 1976). In later years British cultural studies was exported to the United States, Canada and Australia, but the focus of research shifted to marginal, minority, subaltern and aboriginal peoples, even though its academic practitioners have been overwhelmingly white and bourgeois, and predominantly male' (Blundell et al. 1993: 5). It appears then that the theory and practice of cultural studies are ironic: it sets out to problematize the culture-society nexus, but in doing so it instantiates the very structure in which the debate is embedded.

Yet, it is within the scope and agenda of cultural studies to struggle against the grain of dominant structures, but to do so requires turning subalterns and minorities into objects of study as well as agents of change. Consider, for example, Agger's (1992: 178) agenda to create 'a deacademized cultural studies metabolized into the lifeworlds of people who make use of cultural studies in order to resist dominant culture and create new culture'; or Grossberg's (1993: 14) mechanic model of power, which 'involves a more explicit spatial territorialization ... [which] requires a notion of affective investment'. These are essentially efforts to empower the notion of culture as both a materialist and symbolic arena of change.

Unlike cultural anthropology, cultural studies is mainly concerned with minorities in the First World and has yet to exert its intellectual 
influence in the Asian sphere. Cultural anthropology took the First World into the Third World (including Asia) and later influenced the Third World to study itself, just as certain aspects of Western sociology had done for Third World intellectualization (Lee 1994b). It took the notion of culture as the beliefs and practices of Asians, non-Western and peripheral peoples (Others) and turned it into a mirror to problematize Western culture (see Gewertz and Errington 1991).

Cultural studies has yet to form coherent bonds with cultural anthropology, but its potential for such an enterprise remains open as its programmes are gradually directed towards an international audience. It would mean that the amorphous identity of cultural studies may reach into or seek a point of contact with the more distinct identity of cultural anthropology, thereby reliving, transforming and projecting the cultural problematic derived from First World intrusions into the Third World in the Third World itself (cf. Turner 1993).

However, the internationalization of cultural studies may increase cultural effectivity in the possible transformation of objects of study into active agents of cultural resistance and creation, both against local dominant structures and the Western sources of intellectualization. In other words, the receptivity of Asians to cultural studies may turn out to be a double-edged sword: it signals an endorsement of the cultural studies agenda but it could eventuate as a weapon against the Western perspectives of cultural studies. This is a consequence of the reflexivity inherent in cultural studies, which may resensitize former colonial subjects to the power of traditions.

\section{The Power of Cultural Representation}

If cultural studies is an intellectual tool for reorganizing representations of Western and Asian identities, we need to understand how this is taking place and the implications of these changes. One approach is to present a specific case of changes in cultural images, which will provide an empirical instance of representational change in terms of cultural critique and the empowerment of new identities. For this purpose, I shall discuss recent changes in the perception of latah as a Malay, culture-bound syndrome. Generally, culture-bound syndromes have been treated as though they were real manifestations of mental illness or as a mental oddity in many Asian (and other non- 
Western) cultures by Western observers for almost half a century (see Yap 1969). Latah is one example of this cultural representation.

More than a century ago, Europeans who worked or travelled in the Malay-Indonesian archipelago observed and reported on a seemingly unusual malady known as latah. This was a reaction noted among Malays (principally older women) who exhibited a wide range of exaggerated and compulsive behaviours, some of which were considered offensive under normal circumstances, upon being provoked, startled or frightened. A comprehensive review of the literature on latah can be found in Winzeler (1984: 104) whose evaluation of colonial scholarship on the syndrome suggested that 'it indicated an important flaw in the Malayan racial character - a tendency more strongly manifest in Dutch than in British accounts, but present in both'.

Winzeler's review (ibid.: 80) shows that the European representation of latah in the 19th century tends to relate it as 'a manifestation of an intensified nervous sensibility' among the Malays. European doctors of that period diagnosed latah as a mental disorder or nervous condition which was difficult to classify. Some colonial administrators attributed this condition to the hot humid Malaysian climate, even believing that a European who spent a few years in the tropics could become jumpy and nervous like the natives (ibid.: 85).

Later accounts by writers influenced by Freudian psychoanalysis focused on the Malay subconscious. In explaining latah, these writers argued that sexual repression combined with infantile-primitiveness among Malay women 'provided the basis for hypersuggestibility and loss of will that occurred with latah' (ibid.: 88). Psychoanalytic approaches to latah continued to be used in the 20th century, further elaborating on the sexual dreams of latah women (Murphy 1972). However, some Western psychiatrists who preferred to emphasize the cultural aspects of latah have hypothesized that various manifestations of the syndrome are 'culture specific exploitations of a neurophysically determined behaviour potential' (Simons 1980: 196).

This summary of Western scholarship on latah features some of the characteristics of Orientalism (see Said 1978), in which a form of unusual behaviour hardly observed in the West becomes a locus of moral judgement or scientific speculation on the psychology of an Asian people. Not only was latah perceived by Europeans as a weakness in the Malay personality, but also 'under the stimulus of 
the development of medical psychology ... a "mental disorder", one which resembled the hysteria already thought to be present among European women' (Kenny 1978: 213). To conceptualize latah in European terms as a psychological problem was relatively easy, since '[d]uring the colonial era, the relationship between the societies of the individuals who studied latah and those of the latah persons they studied was very unequal' (Winzeler 1984: 104). The helplessness of the Malay colonial subject became the very reason for the attribution of weakness to his character as European scholars and doctors found so readily in the expression of latah.

The trend towards deconstructing latah began with Kenny's (1978, 1983, 1990) critique and re-evaluation of the syndrome as an artefact of the Western colonial encounter with the Asian 'other'. As Winzeler (1984: 104) puts it, '[Kenny] wants to show that latah is not evidence of the weakness of the Malayan character or the female psyche, which earlier colonial interpreters held to be, but rather of strength.' In other words, the latah person challenges the marginality of her social position by parodying her superiors through obscene and undignified conduct.

Furthermore, Kenny (1990: 138) believes that indigenous categories of explaining latah should be given priority over European psychological ones: '[Latah] has a demonstrable internal relationship to the culture of the region - to local theories about the constitution of the person as a psycho-physical being, and to metaphysical notions about the relation of the self to the wider world.' Herein lies Kenny's real challenge to Orientalism - that the self-effacing theories of powerlessness in latah offered by Western colonial scholarship understate the nature of the natives' will, which requires understanding on its own terms. Hence, the deconstruction of latah is a comment on the imposition of Western cultural categories on a selfcontained Asian system of cognition and behaviour with its own logic and rules. In this critique of Western colonial scholarship, it is not so much the liberation of the indigenous self that is at stake but that of the Western mind in its encounter with the Asian other.

\section{Postcolonialism and Multiculturalism}

The postcolonial critique of Western cultural analysis is also a postmodern endeavour to raise Western consciousness of the 
alternative strength of indigenous categories. If these categories eventually gain some independence as tools for a re-examination of modernity, then the task of deconstruction may be directed towards a more serious undertaking for the rewriting of Western culture.

Yet the problem of cultural identity in postcolonial Asian societies is not as clear-cut as it seems. Even though Western colonialism had introduced new cultural forms into the traditional patterns of Asians and other non-Western peoples, it did not unilaterally erase the memory of these patterns or marginalize them in the process of modernization. On the contrary, many traditional practices were used as forms of resistance to colonialism. Sometimes, however, these practices were interpreted as obstacles to development. This difference in attitude towards traditions comprises a critical moment in postcolonial Asian societies that bifurcates the experience of contact with the West into cooptative and resistant identities.

In the first instance, cooptation suggests a type of identity that is dependent on the colonial past but uses it to promote a distinct outlook that may be described as 'neo-modern'. For example, in some Asian societies once colonized by Britain, English common law and style of government continue to be practised. There may be local modifications of these institutional systems but their continued presence is taken to affirm the growth and effectiveness of a national culture that has evolved from colonialism into something uniquely modern. Similarly, the globality of the English language as it becomes the stepmother tongue of many Asian peoples provides an instance of modernity that reflects a continuing link between the colonial and postcolonial period.

These linkages do not mean that no resistance is possible. Eagleton (1992: 31-32) has argued that even as 'English responded with the ersatz internationalism of Empire, at once global in reach and securely nation-centred ... [it] contained the seeds of its own deconstruction', these seeds having been sown by postcolonial writing which 'drives a dangerous wedge between signifier and signified, dislocating the nation's speech from its identity'.

This postcolonial writing is indicative of a type of marginality or hybridity, an in-betweenness which allows the postcolonial intellectual to use English or any colonial language as an instrument to articulate a separate identity. This is because the language which postcolonial intellectuals use effectively to represent themselves is also the language 
of imperialism. In other words, any theory or practice of resistance cannot be wholly autonomous. It must draw upon the resources of the colonial past in order to make an impact on the postcolonial present.

The implication is that the power of postcolonial Asian resistance is ironic: the postcolonial Asian intellectual is seen to come of age through Western education to speak against imperialism, as if the absence of such an education would only confine him or her to a little corner in an undeveloped world. Only through imperialist pedagogy, it is assumed, can imperialism be impugned by postcolonial Asian intellectuals. By appropriating the language of imperialism to confront the First World, the postcolonial Asian intellectual is also sensitizing himself or herself to the cultural discontents of Western societies. It is at this juncture that the receptivity of the postcolonial Asian intellectual to cultural studies is most open, because resistance against imperialism may be defined as inclusive of resistance to cultural domination in Western societies.

This sensitivity to domination has now become a distinct issue concerning the expression and maintenance of cultural identities in multicultural environments in the West and Asia. The rediscovery of traditional identities, the creation of marginal identities, and the forging of new national identities reflect the impact of Western colonialism on many Asian peoples. The consequence is not just a continued acceptance or radical rejection of Western representation, but a highly volatile mixture of various representations in postcolonialism.

First, postcolonialism suggests not only the socio-economic retreat of the colonial powers, but also the development of internal critiques by First World intellectuals or Asian intellectuals living in the West. Second, postcolonialism introduces new power relations that are not only problematic for the colonizer and colonized, but particularly among the colonized now seeking to establish multiple identities. Freed from colonial domination, former colonial subjects are asking how and where they belong. There is no one-to-one correspondence between new identities and traditional loyalties in the postcolonial world, but a variety of cultural patterns emerging from the 'juxtapositions or alliances of differently contextualized critique' (Chicago Cultural Studies Group 1992: 538). In short, each cultural discourse carving out a particular representation must face other cultural discourses with varying agendas. Some of these agendas are rooted 
in colonial history which no amount of postcolonial narrativization can effectively erase (cf. Prasad 1992).

The underlying power dimension in postcolonial multiculturalism, therefore, creates at least two problem levels in contemporary cultural representation. First, the postcolonial world has transformed the Western centre of discourse into a polyphonous arena of competing representations. It is no exaggeration for Dirlik (1994: 347) to say that '[t]o mistake fragmentation in one realm with fragmentation in the other ignores the possibility that ideological fragmentation may represent not the dissolution of power but its further concentration.' What this implies for emerging discourses and representations once considered peripheral is that they now have to contend with each other in relation to their power bases. Multiculturalism as an ideology may be invoked to satisfy postcolonial intellectuals who are still under the influence of the civil society paradigm inherited from Western liberals. But it does not prevent dominant groups in postcolonial societies from forcefully advancing their symbols and discourses as the primary frame of representation to the detriment of others. In short, multiculturalism becomes hierarchized as a symbol of power formation in postcolonial plural societies.

Second, multiculturalism as a prevailing slogan of the rapidly decentred Western world may give the impression that postcolonialism invites a greater participation of Asians and non-Western others on the global stage. It suggests that Western decentring is almost synonymous with a voluntarism to let Asians and nonWestern others speak. But among certain intellectuals based in the West, their scepticism has predisposed them towards viewing this voluntarism in realpolitik terms. Thus, Dirlik (1994: 350) believes that

it is arguable that the end of Eurocentrism is an illusion because capitalist culture as it has taken shape has Eurocentrism built into the very structure of its narrative, which may explain why, even as Europe and the United States lose their domination of the capitalist world economy, European and American cultural values retain their domination.

These two problem levels concerning multicultural representation articulate the nature of cultural imperialism and domination in the postcolonial era. The ideology of multiculturalism cannot completely mask or underplay the power positions behind the processes of imageformation. The meaning of culture, as it unfolds within the 
discourse of multiculturalism, needs to be treated in relation to the redefined contours of world development.

\section{Metaphysics of Cultural Power}

The meaning of culture in world development becomes more significant when we compare Western and Asian perceptions of being. The question of being, or the interrogation of the 'whatness' of existence (that is, the possibility of becoming and the actualization of things in the world), comprises a fundamental aspect of the Western philosophical tradition. This is traceable to Parmenides, who allegedly laid the foundation of Western metaphysics as a 'quest for being', a quest that has apparently shaped Western thinking (and by that definition, cultural outlook) for the last 2,400 years. In contrast, Asian (but more specifically, Chinese) philosophical and cultural perspectives are generally more concerned with world accommodation, approaches that are described as 'seeking the way' (see Cheng 1989: 203-206).

A consequence of this distinction between Western and Asian philosophical outlooks is in the way culture is shaped according to an understanding of 'being'. 'Being' in Western thought implies a quest for meaning that attempts to objectify experiences as reality in other words, systematic patterns of reality can be inferred through rational processes from a wide range of experiences in the world. Therefore, being in the Western sense cannot encompass non-being because the latter as an unobjectifiable presence nullifies experience as reality: 'The abhorrence of non-being as a vacuum exists in both [Western] science and metaphysics as the quest for being' (Cheng 1989: 203).

What this implies for Western culture is that meaning must be generated from experiences in order to provide a raison d'être for being, the failure of which results in the truncation of the quest for being. Culturally, this would imply a development of alienation and the need to seek a renewal of meaning. There have been attempts in the Western philosophical tradition to transcend metaphysics through radical critiques, most notably from Nietzsche to Heidegger, but Cheng (1989: 203) argues that they ended up as a continuation of the quest for being in different disguises. (The case of Heidegger is especially interesting since it has been shown recently that his 
philosophy cannot be unequivocally separated from his political activities [see Farias 1989; Zimmerman 1990]).

The shift from class to cultural issues, as discussed above, may be interpreted as a continuation of the quest for being. The source of this quest in the latter part of the 20th century can be attributed to the decline of Western colonialism and the restructuring of Western societies in terms of postindustrial and postmodern concerns. During the colonial period, Western difficulties with apprehending non-being were readily channelled into the colonized periphery in Asia and elsewhere. Cultural power in Western colonialism rested not only on economic and technological achievements, but also on the generation of hegemonic meanings that revitalized being and kept non-being at bay in the colonized periphery.

The metaphysics of cultural power in the colonial period suggests that the quest for being was sought in a closed system of hegemonic concepts, juxtaposed against non-being and all that defied rational scrutiny. All this changed in the postcolonial, postindustrial and postmodern period, when the dominant presence of being could no longer be adequately defined within the established system of hegemonic concepts. The preponderance of cultural issues, the rise of new social movements, the critique of representations, and the redefinition of politics in the West point to a renewed effort in the quest for being that seeks to readjust relations between reason, the self, and the lifeworld.

In contrast to Western metaphysics, Cheng (1989: 205) describes Chinese (and for that matter, other Asian) metaphysics as nonmetaphysics in the sense of a reduced importance of the quest for being. The system that Cheng calls 'seeking the way' is more concerned with the complementarity of being and non-being, rather than the opposition between being and non-being. Culturally, this implies that transformation of meanings is seen as a natural aspect of worldly existence, and cannot be resisted. Non-being is not perceived as antagonistic to being; rather being is said to emerge from non-being. This system suggests the possible development of accommodative attitudes that substitute opportunistic insertion for cultural estrangement.

The intricate relationship between being and non-being, as developed in Chinese and other Asian philosophies, is beyond the scope of this essay. However, postcolonial and postmodern developments 
suggest that the crisis of being in the West has provided a niche for the emergence of specific Asian identities, which had once been relegated to the sphere of non-being in contrast to the hegemonic being of Western colonialism. The metaphysics of cultural power in the postcolonial and postmodern context suggests an ironic reversal. The quest for being in the Western sense has resulted in disillusionment with reason, technology and individual autonomy. The reversal of this quest to seek rapprochement with non-being, as an alternative to the voracious expansion of being, has increased Western receptivity to Asian religious and philosophical systems. On the other hand, Asian efforts in postcolonial emancipation have increased perceptions of autonomy in nation-building and hopes for cultural renewal (see Anwar 1996). These efforts suggest a postcolonial Asian quest for being, which may not necessarily accommodate itself to non-being. On the contrary, non-being may be rejected as an obstacle to social and cultural development in the context of Asian modernization.

These changes in the metaphysics of cultural power challenge the notion of Asian passivity and world accommodation. The quest for meaning in Asian modernization implies a revival of Asian identities in world development, a revival that is occurring in the context of Western cultural problematics.

\section{Conclusion: Asian Identities in World Development}

The old modernization paradigm constructed from Enlightenment thought attributed progress to the passing of tradition and the subordination of cultural identities to a centre of unfolding scientific knowledge and universal truth. Metaphysically, this was the centre of a rational being. Culture was construed as antediluvian because it was rooted in particularities and reflected a past which allegedly obstructed the historic breakthroughs of human endeavours. Classical Marxism stressed the historic role of revolutionary labour but not its cultural elements. Non-Marxian modernization theorists paid much attention to the structural dimensions of social change but not necessarily to its cultural underside. However, the advent of postmodernism has disprivileged the search for universal truth in the name of a resilient pluralism that opens the way for the return of cultural identities. This does not imply that modernity and its logocentric pursuit of a world development are now at an end, but 
that any notion of development cannot possibly ignore culture as an autonomous force.

World development at the end of the 20th century has mellowed into a concern over representational space rather than economic hegemony. From the 1960s to the 1980s, dependency theory and world-system theory approached development as a function of uneven capital accumulation and labour organization between industrial and industrializing countries. But in the 1990s, worldsystem theorists such as Wallerstein (1990) have begun to address the role of culture in developmental processes. This emerging position complements to a certain extent the culture-oriented perspectives of the globalization theorists (e.g. Robertson 1992). These theoretical changes suggest that the Marxian distinction between base and superstructure can no longer be taken as a fundamental criterion of world development. Cultural ideologies and practices based on traditional patterns of life have acquired a status that does not explicitly require their subordination to an economic base as a viable theory of development. On the contrary, the new paradigm of world development stresses an inseparability of structure and culture that places the question of renewal and reproduction at the forefront. This implies that culture is not a static entity but interacts with global capital to manifest different forms and effects. In the metaphysical sense, the quest for being has now been redefined by this unique conjunction of culture and global capital.

In this paradigm shift, the autonomy of culture is treated on two levels: the global and the local. First, culture as a global phenomenon refers to its commoditization as an assembled product of transnational capital and items of tradition and customary behaviour. In this sense, culture is seen as a sign that is not deterministically rooted in traditional referents, but is connected to other signs by capital in order to free-float in the space of consumption around the world (cf. Gottdiener 1995). Hence, international chain-stores, franchises, theme parks and shopping malls are considered aspects of global culture, since they are found in many parts of the world where transnational capital has made an impact on the local economy. Global culture is imperialistic to the extent that it penetrates and influences local cultures without overt coercion or explicit subjugation. Rather, it dominates through consumption and pleasure without necessarily arousing a sense of deprivation. 
However, the emergence of cultural studies as a focus on the sources and consequences of cultural reproduction has transformed reflexivity into a systematic critique of and intellectual resistance to global culture. Because cultural studies has yet to become a coherent discipline with a well-integrated agenda, its impact on world development is still not clear. This ambiguity of cultural studies suggests that its appropriation by Asian and non-Western intellectuals could be modified into a programme of cultural resistance to Western cultural forms.

Second, the potentiality of cultural studies as resistance implies the reworking of Asian identities into vehicles of cultural assertiveness in world development. It is in postcolonialism that the power of tradition has become more pronounced. The freeing of cultural elements in postcolonialism, which has contributed to the construction of global culture, suggests that development can no longer be based solely on an economic vision of growth. Asian identities premised on the tenacity of tradition are becoming more significant, not only as a response to global culture but also as a platform for remoulding the concept of development in terms of Asian values. The redefinition of Confucian values in East Asian development provides a good example of tradition as a resource for altering the meaning of world development (see Lee 1997).

But as Asian identities gain more significance in delineating the contours of development and change, they also accentuate differences in traditional and political claims. In postcolonialism these claims are no longer adjudicated by a colonial authority, but by a coalition or a dominant group that reflects the conditions of local politics. For this reason, the issue of multiculturalism has surfaced as an important factor not only in the deconstructive agenda of Western postmodernism, but also in the renewal of modernity in many Asian societies. Multiculturalism in Western postmodernism functions as a critical statement and programme against logocentrism. However, multiculturalism in Asian modernization reflects the problem of power-sharing and identity-formation in the processes of nation-building.

These complexities emerging from the confluence of Western postmodernism and Asian modernization suggest that world development has lost its teleological drive. The ends of modernization premised on a vision of secular and scientific development in 
which the world moves in a single direction, to achieve a single quest for being, is now at an end. The crisis of being and structural changes in the West have contributed to a revision of world development that must simultaneously reflect the realities of transnational capital, tradition, technology, multiculturalism and resistance. These realities suggest that world development will continue but at a pace that is influenced by an indeterminate relationship between Western cultural critique and Asian identity renewals.

Raymond Lee, Associate Professor, Department of Anthropology \& Sociology, University of Malay, 50603 Kuala Lumpur, Malaysia. Fax: (60) 603-759 5459, e-mail: f2lmlee@cc.um.edu.my. Together with Susan Ackerman, author of Heaven in Transition and Sacred Tensions. Research in social theory, religion and ethnicity.

\section{REFERENCES}

Ackerman, S. and Lee, R. (1988) 'Heaven in Transition'. Non-Muslim Innovation and Ethnic Identity in Malaysia. University of Hawaii Press

- (1997) 'Sacred Tensions'. Modernity and Religious Transformations in Malaysia. University of South Carolina Press.

Agger, B. (1992) Cultural Studies as Critical Theory. London: Falmer Press.

Anwar, Ibrahim (1996) The Asian Renaissance. Singapore: Times International.

Aronowitz, S. (1992) The Politics of Identity. London: Routledge.

Blundell, V., Shepherd, J., and Taylor, I. (1993) 'Introduction', in V. Blundell et al. (eds.) Relocating Cultural Studies. London: Routledge, pp. 1-17.

Cheng, Chung-Ying (1989) 'Chinese Metaphysics as Non-Metaphysics: Confucian and Daoist Insights into the Nature of Reality', in R.E. Allinson (ed.) Understanding the Chinese Mind. New York: Oxford University Press, pp. 167-208.

Chicago Cultural Studies Group (1992) 'Critical Multiculturalism'. Critical Inquiry 18: 530-55.
Crook, S., Pakulski, J., and Waters, M. (1992) Postmodernization: Change in Advanced Society. London: Sage.

Dirlik, A. (1994) 'The Postcolonial Aura: Third World Criticism in the Age of Global Capitalism'. Critical Inquiry 20: 328-56.

Eagleton, T. (1992) 'The Crisis of Contemporary Culture'. New Left Review 196: 29-41.

Farias, V. (1989) Heidegger and Nazism. Philadelphia: Temple University Press.

Gewertz, D., and Errington, F. (1991) 'We Think, Therefore They Are? On Occidentalizing the World'. Anthropological Quarterly 64: 80-91.

Gottdiener, M. (1995) Postmodern Semiotics, Oxford: Blackwell.

Grossberg, L. (1993) 'Cultural Studies and/in New Worlds'. Critical Studies in Mass Communications 10: 1-22.

Hall, J.R., and Nietz, M.J. (1993) Culture: Sociological Perspectives. Englewood Cliffs: Prentice Hall.

Hall, S., and Jefferson, T. (eds.) (1976) Resistance through Rituals. London: Hutchinson. 
Harris, D. (1992) From Class Struggle to the Politics of Pleasure. London: Routledge.

Hebdige, D. (1988) Hiding in the Light. London: Routledge.

Inglis, F. (1993) Cultural Studies. Oxford: Blackwell.

Jenks, C. (1993) Cultural Reproduction. London: Routledge.

Kenny, M.G. (1978) 'Latah: The Symbolism of a Putative Mental Disorder'. Culture, Medicine and Psychiatry 2: 209-31.

- (1983) 'Paradox Lost: The Latah Problem Revisited'. Journal of Nervous and Mental Disease 171: 159-67.

- (1990) 'Latah: The Logic of Fear', in W.J. Karim (ed.) Emotions of Culture. Singapore: Oxford University Press, pp. 123-41.

Lash, S., and Urry, J. (1987) The End of Organized Capitalism. Cambridge: Polity.

Lee, R.L.M. (1994a) 'Modernization, Postmodernism and the Third World'. Current Sociology 42 (2): 1-66.

- (1994b) 'Global Sociology or "Ghettoized" Knowledges? The Paradox of Sociological Universalization in the Third World'. The American Sociologist 25: 59-72.

- (1997) 'The Limits and Renewal of Modernity: Reflections on World Development and Asian Cultural Values'. International Sociology 12 (forthcoming).

Marien, M. (1993) 'Cultural Trends, Troubles and Transformations'. Futures 25: 414-30.

Melucci, A. (1989) Nomads of the Present. Philadelphia: Temple University Press.

Mouffe, C. (1988) 'Radical Democracy: Modern or Postmodern?', in A. Ross, (ed.) Universal Abandon: The Politics of Postmodernism. Minneapolis: University of Minnesota Press, pp. 31-45.

Murphy, H.B.M. (1972) 'History and the Evolution of Syndromes: The
Striking Case of Latah and Amok', in M. Hammer et al. (eds.) Psychopathology. New York: Wiley, pp. 33-55.

Petras, J., and Vieux, S. (1994) 'The Decline of Revolutionary Politics: Capitalist Detour and the Return of Socialism'. Journal of Contemporary Asia 24: 1-34.

Prasad, M. (1992) "The "Other" Worldliness of Postcolonial Discourse: A Critique'. Critical Quarterly 34: 74-89.

Robertson, R. (1992). Globalization. London: Sage.

Said, E. (1978) Orientalism. New York: Vintage.

Simons, R. (1980) 'The Resolution of the Latah Paradox'. Journal of Nervous and Mental Disease 168: 195-206.

Smith, A.D. (1990) 'Towards a Global Culture?', in M. Featherstone (ed.) Global Culture. London: Sage, pp. 171-91.

Steinmetz, G. (1994) 'Regulation Theory, Post-Marxism, and the New Social Movements'. Comparative Studies in Society and History 36: 176212.

Turner, T. (1993) 'Anthropology and Multiculturalism: What is Anthropology that Multiculturalists Should Be Mindful of It?' Cultural Anthropology 8: 411-29.

Wallerstein, I. (1990) 'Culture as the Ideological Battleground of the Modern World-System'. Theory, Culture and Society 7: 31-55.

Winzeler, R. (1984) 'The Study of Malayan Latah'. Indonesia 37: 77-104.

Yap, P.M. (1969) 'The Culture-Bound Reactive Syndromes', in W. Caudill and T.Y. Lin (eds.) Mental Health Research in Asia and the Pacific. Honolulu: East-West Center, pp. 33-53.

Zimmerman, M. (1990) Heidegger's Confrontation with Modernity. Bloomington: Indiana University Press 